\title{
Length-weight relationship of sucker head, Garra Gotyla Gotyla (Gray, 1830) in different rivers of Nepal and the influence of monsoon
}

\author{
${ }^{1}$ B. R. Jha, ${ }^{2} \mathrm{H}$. Waidbacher, ${ }^{1}$ S. Sharma and ${ }^{2} \mathrm{M}$. Straif \\ ${ }^{1}$ Kathmandu University, Dhulikhel, P. O. Box 6250, Kathmandu, Nepal \\ ${ }^{2}$ Universität für Bodenkultur, Max Emanuel-Straße 17 A-1190 Wien, Austria
}

\begin{abstract}
Size structure data particularly that of length and weight is very important fisheries management tool, which is also applied to assess the health, habitat and integrity of the rivers. Nepal is tremendously rich in both fisheries and water resource and thus, this analysis is very important. However, this kind of analysis is not common in fisheries studies and hence the size structure information of all the fish in Nepal is wanting. This study simply tries to open the door for such studies with the study of the sucker head Garra gotyla gotyla, a very common fish in Nepal. The field observation was done in nine rivers of the country in all the seasons of the 2003 by using electrofishing gear. The length-weight relationship was found to vary both spatially and temporally among rivers and seasons respectively indicating different conditions in different rivers. The length weight relationship also showed some interesting facts about the seasonal cycle of the species indicating the period of growth and stress in different rivers. The monsoon event was found to be highly influential in this relationship.
\end{abstract}

Key words: Garra gotyla gotyla, length-weight relationship, electrofishing, river, monsoon

*Corresponding Author, E-mail: jhabibhuti@gmail.com

\section{Introduction}

Length and weight data are useful and standard results of fish sampling programs (Morato, et al., 2001). Such data are essential for a wide number of studies, for example estimating growth rates, age structure and other aspects of fish population dynamics. Study of the size structure in riverine fish reveals many ecological and life-history traits such as the river health, stock conditions and breeding period of the fish. The size structure of a fish population at any point in time can be considered a 'snapshot' that reflects the interactions of the dynamic rates of recruitment, growth and mortality (Neumann, 2001). From length and weight of fish there are methods to determine the ages (Bagenal and Tesch (1978), which together with the abundance (catch per unit effort) give details of the different disturbance regime of the rivers, breeding ground and breeding seasons, the general health of the stock, density and biomass, and the status of the species. Length-weight regressions have been extensively used to estimate weight from length because of technical difficulties and the amount of time required to record weight in the field (Morato, et al., 2001). Therefore, the size structure analysis is one of the most commonly used fisheries assessment tools. Although size structure analysis is a standard and regular method to evaluate the conditions of both rivers and stocks in developed countries of North America and Europe, it has just started in the developing countries. Nepal, with a huge amount of water resource, has a tremendous potential for fisheries development. A total of 182 species belonging to 93 genera under 31 families and 11 orders has been reported from Nepal (Shrestha, 2001). Some information on ecological and population characteristics of the fish, such as region and altitude of occurrence, habitat preference, temperature range, maximum length, feeding habit, life history and a crude status of many of the fish species are available. However, the size structure analysis, which is so important in fisheries management, is clearly lacking in the Nepalese fish species. This paper presents and analyses the lengthweight relationship of sucker head, Garra gotyla gotyla (Gray, 1830), a widely distributed and important fish species of the region (Figure 1). This fish, commonly called as Buduna in Nepal, has been listed by Rajbanshi (1982), Ataur Rahman (1989), Shrestha (1990), Talwar and Jhingran (1991), Shrestha (1994) and Shrestha (2001) under the same name or different synonyms. It is reported from Afghanistan, Pakistan, India, Nepal, Bangladesh, 


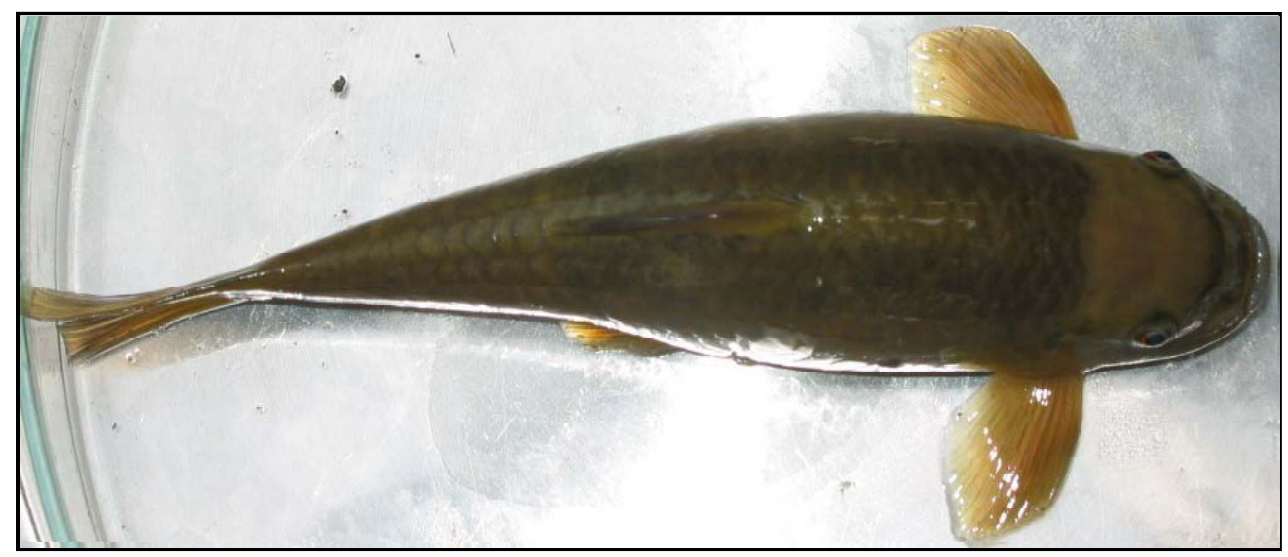

Figure 1: Garra gotyla gotyla (Gray, 1830)

Bhutan and Burma. In Nepal the species has been reported from up to 1560 masl with maximum size of $150 \mathrm{~mm}$. It has been included as coldwater fish of Nepal by Shrestha (1999) and Swar (2001). It is not included in IUCN red list and reported as 'fairly common' in the country. The present work finds it in all the rivers studied except river Bagmati and is perhaps one of the most common species. It is a harmless fish feeding on algae, plants and detritus (fishbase.org).

The importance of the fish has been mentioned as minor commercial by Talwar and Jhingran (1991). However, due to high value as a food fish as well as its distribution, this species has a potential to become important protein source to the poverty-ridden population of Nepal. But there is hardly any method developed to assess the population dynamic of the species nor is there any example of using it as an indicator for the impact of various disturbances. This is the first description of length-weight relationship of Garra gotyla. In Nepalese context, even a basic work regarding size structure description and distribution is of great value for reference as well as for comparison for future studies. The main objectives of this work are (1) to develop empirical models of length and weight relationship, (2) to see if there is any seasonal variation in length-weight relationship, (3) to see if there is any spatial variation in length-weight relationship among different river systems, and (4) to evaluate and interpret the river conditions, fish health and some life history traits based on length-weight relationship.

\section{Study area}

Altogether nine rivers from central and western region of Nepal were studied for this work. The selection of site was done with main objective of including rivers and streams that are perfect representatives of the disturbances from dams and weirs, agriculture, industry and urbanization. However, there are other factors too, which were considered, such as, similarity in origin of the river, accessibility etc. Accordingly the rivers selected were, Aandhikhola, Arungkhola, Bagmati, Jhikhukhola, Karrakhola, Narayani, East Rapti, Seti and Tinau. Except for Narayani and Seti rivers, which were included due to popular demand, all other rivers originate from midhills. The six rivers, Aandhikhola, Arungkhola, Karrakhola, Narayani, East Rapti and Seti are the members of Gandaki River system, Jhikhukhola is a tributary of Koshi River System, and Tinau and Bagmati are independent systems (Sharma, 1977). Among these all the rivers except Narayani are wadeable rivers at least during period other than monsoon. There were 23 sampling sites covering those nine rivers. Table 1 shows the exact coordinates of all the sampling sites.

\section{Materials and Methods}

Fish sampling was done using electro fishing gear and this could be the first application of electro fishing gear for fish sampling in Nepal, as there are no records. The method followed here was a simple but standard wading type with a person carrying a backpack electro-fishing unit. He was assisted by two persons each carrying a long dip nets to collect the shocked fish and a third person carrying a bucket to empty the nets. For the safety, all the persons involved in fishing were insulated by a long wading boots. In each site, the fish sampling was done in two runs, 1 and 2 respectively. The stretch of each sampling site was mostly between 50 to 100 meters. The time span for each run was taken separately, which is an important factor to calculate the catch per unit effort (CPUE). This in turn is important tool to see other population dynamics of the fish. The time for each run were tried to be fixed around 
Table 1: Description of the sampling sites

\begin{tabular}{|c|c|c|c|}
\hline Rivers & Sites - Upstream & Sites - Downstream & Sites - Downstream \\
\hline Aandhikhola & $\begin{array}{l}\text { Bayatari } \\
27^{\circ} 58^{\prime} 29.6^{\prime \prime} \text { lat. } \\
83^{\circ} 43^{\prime} 1.6^{\prime \prime} \text { long. } \\
681 \text { masl }\end{array}$ & $\begin{array}{l}\text { Galyang } \\
27^{\circ} 56^{\prime} 55.2^{\prime \prime} \text { lat. } \\
83^{\circ} 40^{\prime} 33.1^{\prime \prime} \text { long. } \\
670 \text { masl }\end{array}$ & \\
\hline Arungkhola & $\begin{array}{l}\text { Kusunde } \\
27^{\circ} 37^{\prime} 7.5^{\prime \prime} \text { lat. } \\
83^{\circ} 57^{\prime} 20^{\prime \prime} \text { long. } \\
148 \text { masl }\end{array}$ & $\begin{array}{l}\text { Kusunde } \\
27^{\circ} 36^{\prime} 30.7^{\prime \prime} \text { lat. } \\
83^{\circ} 57^{\prime} 20.5^{\prime \prime} \text { long. } \\
140 \text { masl }\end{array}$ & \\
\hline Bagmati & $\begin{array}{l}\text { Sundarijal } \\
27^{\circ} 46^{\prime} 24.9^{\prime \prime} \text { lat. } \\
85^{\circ} 25^{\prime} 33.8^{\prime \prime} \text { long. } \\
1621 \text { masl }\end{array}$ & $\begin{array}{l}\text { Sundarijal } \\
27^{\circ} 46^{\prime} 18.4^{\prime \prime} \text { lat. } \\
85^{\circ} 25^{\prime} 34.5^{\prime \prime} \text { long. } \\
1610 \text { masl }\end{array}$ & \\
\hline Jhikhukhola & $\begin{array}{l}\text { Paanchkhal } \\
27^{\circ} 38^{\prime} 55.3^{\prime \prime} \text { lat. } \\
85^{\circ} 35^{\prime} 28.5^{\prime \prime} \text { long. } \\
936 \text { masl }\end{array}$ & $\begin{array}{l}\text { Paanchkhal } \\
27^{\circ} 36^{\prime} 24.4^{\prime \prime} \text { lat. } \\
85^{\circ} 39^{\prime} 33.4^{\prime \prime} \text { long. } \\
898 \text { masl. }\end{array}$ & \\
\hline Karrakhola & $\begin{array}{l}\text { Hetauda } \\
27^{\circ} 24^{\prime} 30.8^{\prime \prime} \text { lat. } \\
85^{\circ} 03^{\prime} 09.6^{\prime \prime} \text { long. } \\
450 \text { masl }\end{array}$ & $\begin{array}{l}\text { Hetauda } \\
27^{\circ} 24^{\prime} 53.7^{\prime \prime} \text { lat. } \\
85^{\circ} 01^{\prime} 09^{\prime \prime} \text { long. } \\
450 \text { masl }\end{array}$ & \\
\hline Narayani & $\begin{array}{l}\text { Narayanghat } \\
27^{\circ} 42 \text { ' } 16.1^{\prime \prime} \text { lat. } \\
84^{\circ} 24^{\prime} 50^{\prime} \text { long. } \\
165 \text { masl. }\end{array}$ & $\begin{array}{l}\text { Narayanghat - city } \\
27^{\circ} 41^{\prime} 51.1^{\prime \prime} \text { lat. } \\
84^{\circ} 24^{\prime} 50^{\prime \prime} \text { long. } \\
165 \text { masl }\end{array}$ & $\begin{array}{l}\text { Narayanghat -industry } \\
27^{\circ} 41^{\prime} 40.8^{\prime \prime} \text { lat. } \\
84^{\circ} 24^{\prime} 7.3^{\prime \prime} \text { long. } \\
162 \text { masl }\end{array}$ \\
\hline Rapti & $\begin{array}{l}\text { Hetauda } \\
27^{\circ} 27^{\prime} 10.9^{\prime \prime} \text { lat. } \\
85^{\circ} 02^{\prime} 19.5^{\prime \prime} \text { long. } \\
451 \text { masl }\end{array}$ & $\begin{array}{l}\text { Bhandara } \\
27^{\circ} 34^{\prime} 14^{\prime \prime} \text { lat. } \\
84^{\circ} 38^{\prime} 54.8^{\prime \prime} \text { long. } \\
202 \text { masl }\end{array}$ & \\
\hline Seti & $\begin{array}{l}\text { Pokhara } \\
28^{\circ} 15^{\prime} 12.8^{\prime \prime} \text { lat. } \\
83^{\circ} 58^{\prime} 4.5^{\prime \prime} \text { long. } \\
927 \text { masl }\end{array}$ & $\begin{array}{l}\text { Pokhara } \\
28^{\circ} 9^{\prime} 39.4^{\prime \prime} \text { lat. } \\
84^{\circ} 0^{\prime} 56.1^{\prime \prime} \text { long } \\
630 \text { masl }\end{array}$ & \\
\hline Tinau & $\begin{array}{l}\text { Maniphant - Agriculture } \\
27^{\circ} 49^{\prime} 22.3^{\prime \prime} \text { lat. } \\
83^{\circ} 36^{\prime} 9.6^{\prime \prime} \text { long. } \\
680 \text { masl }\end{array}$ & $\begin{array}{l}\text { Koldanda - Agriculture } \\
27^{\circ} 47^{\prime} 52.2^{\prime \prime} \text { lat. } \\
83^{\circ} 31^{\prime} 37.6^{\prime \prime} \text { long. } \\
616 \text { masl }\end{array}$ & \\
\hline Tinau & $\begin{array}{l}\text { Butwal - Dam } \\
27^{\circ} 44^{\prime} 11.6^{\prime \prime} \text { lat. } \\
83^{\circ} 27^{\prime} 52.9^{\prime \prime} \text { long. } \\
282 \text { masl }\end{array}$ & $\begin{array}{l}\text { Butwal - Dam } \\
27^{\circ} 43^{\prime} 32.8^{\prime \prime} \text { lat. } \\
83^{\circ} 28^{\prime} 6.3^{\prime \prime} \text { long. } \\
207 \text { masl }\end{array}$ & \\
\hline Tinau & $\begin{array}{l}\text { Butwal - city } \\
27^{\circ} 43^{\prime} 18.7^{\prime \prime} \text { lat. } \\
83^{\circ} 28^{\prime} 5.6^{\prime \prime} \text { long. } \\
171 \text { masl }\end{array}$ & $\begin{array}{l}\text { Butwal - city } \\
27^{\circ} 41^{\prime} 37.5^{\prime \prime} \text { lat. } \\
83^{\circ} 27^{\prime} 38.3^{\prime \prime} \text { long. } \\
152 \text { masl }\end{array}$ & \\
\hline
\end{tabular}

20 minutes and was never less than 30 minutes for the total of run 1 and 2 in any of the sample in all seasons. Consistent sampling design for each site in each season was applied to avoid biased results. The first set of field sampling of this study in selected river sections of Nepal began on the third week of February 2003 on the onset of spring season. Prior to that selection of appropriate sampling sites and testing of some of the equipments were carried out since October 2002. After the first real sampling, replicate of it were taken corresponding to all major seasons, summer or pre-monsoon, autumn or post monsoon and winter. Finally four sets of data representing each season, spring, summer/premonsoon, autumn/post monsoon and winter were collected spanning until the beginning of 2004. With 23 sites and four replicate of these, there are altogether 92 samplings that constitute this work. The total lengths of all fishes were measured up to the last $5 \mathrm{~mm}$ with the help of a specially constructed 
simple mechanical devise. The measuring range of this tool was $0-1000 \mathrm{~mm}$. Several weights were also measured for each length group with a portable device starting with the reading of minimum of 2 gm and with the interval of $1 \mathrm{gm}$ thereafter. Latitude, longitude and altitude of the sites were also measured by a portable GPS device.

\section{Results}

The length-weight relationship, which is an important attribute in assessing the health of the fish, to calculate the biomass and to manage the stock was formulated for the Garra species using nonlinear regression and was compared for the seasons and river systems. Among the eight rivers from Nepal where the species was recorded, Aandhikhola, Arungkhola, Karrakhola, East Rapti, Narayani and Seti rivers constitute the Gandaki system; Jhikhukhola belongs to the Koshi system, whereas Tinau is taken as an independent system. The details of the regression of seasonal variations of lengthweight relationship are shown in Table 2. Seasonal variation of length-weight relationship of this species gives very interesting picture corresponding to its life history as well as physiological stress (Figure 2). Looking at the regression, the healthiest fish or the highest biomass was found in pre-monsoon or summer season while the least biomass was in autumn. The relationship has the highest coefficient in pre-monsoon or summer (0.0260) and lowest in post monsoon or autumn (0.0227). Thus, the curve is sharpest or steepest in pre-monsoon while opposite in post monsoon or autumn. Between these seasons there is an interval of just about 3 or 4 months, but perhaps the event monsoon in this interval time seems a very big factor in determining the health and biomass of the fish. For example, according to this regression, a sucker head measuring $180 \mathrm{~mm}$ in length measured $60 \mathrm{gm}$ in autumn whereas the same size weighed as much as 110 gm in summer or premonsoon. The coefficients were intermediate in spring and in winter, and hence the curves too were moderate and lied between the curves of premonsoon and post monsoon. The relationship of length and weight of sucker heads also varied between different river systems of Nepal. Since the coefficient of the curve was found to be highest in pre-monsoon and lowest in autumn, the lengthweight relationship of the species in these two seasons are compared here. The details of the statistics for all three river systems are given in Table 3. Another reason to compare the length-weight relationship between these seasons is because the number of sucker heads collected was highest in autumn/post monsoon and lowest in summer/premonsoon. In pre-monsoon, the coefficient of curve was highest in Gandaki System at 0.0261 whereas both the Koshi and Tinau System had a same lower value of 0.0241 . The regression showed that until the length $95 \mathrm{~mm}$ the sucker heads in all the river systems had the same growth and biomass as they measured same around $10 \mathrm{gm}$. However the growth seemed to differ from that point in this season and in Gandaki System it is more rapid. For example, the sucker head measuring $180 \mathrm{~mm}$ in this season was found to measure as much as $110 \mathrm{gm}$, while in the other systems it was lowly 76 gm (Figure 3). Interestingly, the coefficient of the curve was found to be highest in Koshi River System at 0.0257, while it was lowest in Gandaki system at 0.0226 in post monsoon season. The value was intermediate in Tinau System where it was found to be 0.0240 . Thus, the curve is highest in Koshi System and lowest in Gandaki System with Tinau fitting in between the two. Until the length $80 \mathrm{~mm}$, the corresponding weights were found to be more or less same in all the river systems at around $7 \mathrm{gm}$, but after that the weight gradually fell apart. For example, the sucker head measuring $180 \mathrm{~mm}$ in Koshi System was calculated to be $102 \mathrm{gm}$ while the same total length in Gandaki System was around $58 \mathrm{gm}$.

Table 2: The details of the statistics of length-weight relationship for each season

\begin{tabular}{|lllll|}
\hline $\begin{array}{l}\text { Seasons } \\
\text { Details }\end{array}$ & Spring & $\begin{array}{l}\text { Pre-monsoon or } \\
\text { Summer }\end{array}$ & $\begin{array}{l}\text { Post monsoon or } \\
\text { Autumn }\end{array}$ & Winter \\
\hline Regression & Nonlinear & Nonlinear & Nonlinear & Nonlinear \\
Equation & $\mathrm{f}=\exp \left(\mathrm{a}^{*} \mathrm{x}\right)$ & $\mathrm{f}=\exp \left(\mathrm{a}^{*} \mathrm{x}\right)$ & 0.89885934 & $\mathrm{f}=\exp \left(\mathrm{a}^{*} \mathrm{x}\right)$ \\
$\mathrm{R}$ & 0.94697814 & 0.92296271 & 0.80794811 & 0.90196702 \\
$\mathrm{R}^{2}$ & 0.89676761 & 0.85186016 & 0.000100 & 0.000100 \\
Tolerance & 0.000100 & 0.000100 & 100 & 100 \\
Step size & 100 & 100 & 1000 & 1000 \\
“'Iterations & 1000 & 1000 & 0.0227 & 0.0245 \\
Coefficient $(\mathrm{a})$ & 0.0241 & 0.0260 & 0.0001 & 0.0001 \\
Std. Error & 0.0002 & 0.0002 & & \\
\hline
\end{tabular}




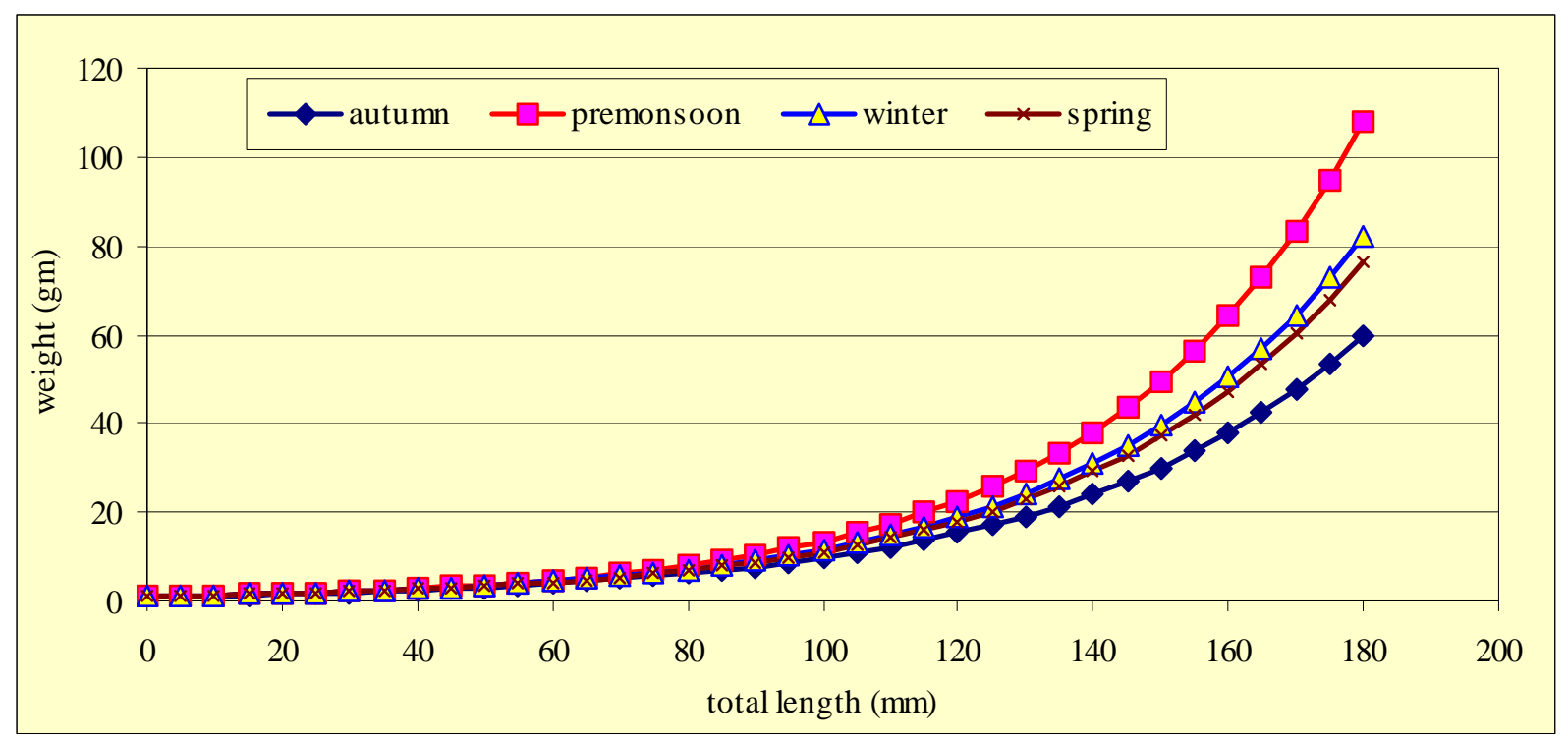

Figure 2: Length-weight relationship of Garra gotyla gotyla in different seasons

The weight for the same length in Tinau however was found to be intermediate between those two at around 75 gm. Thus, the length-weight relationship of the species in three river systems was found to be significantly different (Figure 4). The length- weight relationship of the same river system in these two seasons also showed interesting trends. The Koshi System was found to have higher coefficient of the curve in post monsoon season (0.0257) in comparison with pre-monsoon (0.0241).

Table 3: Summary of the statistics of three river systems in pre-monsoon and post monsoon seasons

\begin{tabular}{|lllllll|}
\hline \multicolumn{1}{c}{$\begin{array}{c}\text { River } \\
\text { Systems } \\
\text { Details }\end{array}$} & \multicolumn{2}{c}{ Koshi } & \multicolumn{2}{c}{ Tinau } & \multicolumn{2}{c|}{ Gandaki } \\
\cline { 2 - 7 } & Pre-monsoon & Post monsoon & Pre- monsoon & Post monsoon & Pre-monsoon & Post monsoon \\
\hline Regression & Nonlinear & Nonlinear & Nonlinear & Nonlinear & Nonlinear & Nonlinear \\
Equation & $\mathrm{f}=\exp \left(\mathrm{a}^{*} \mathrm{x}\right)$ & $\mathrm{f}=\exp \left(\mathrm{a}^{*} \mathrm{x}\right)$ & $\mathrm{f}=\exp \left(\mathrm{a}^{*} \mathrm{x}\right)$ & $\mathrm{f}=\exp \left(\mathrm{a}^{*} \mathrm{x}\right)$ & $\mathrm{f}=\exp \left(\mathrm{a}^{*} \mathrm{x}\right)$ & $\mathrm{f}=\exp \left(\mathrm{a}^{*} \mathrm{x}\right)$ \\
$\mathrm{R}$ & 0.89734577 & 0.95172228 & 0.82110163 & 0.85992448 & 0.92624661 & 0.90389843 \\
$\mathrm{R}^{2}$ & 0.80522944 & 0.90577530 & 0.67420788 & 0.73947011 & 0.85793277 & 0.81703237 \\
Tolerance & 0.000100 & 0.000100 & 0.000100 & 0.000100 & 0.000100 & 0.000100 \\
Step size & 100 & 100 & 100 & 100 & 100 & 100 \\
"'Iterations & 1000 & 1000 & 1000 & 1000 & 1000 & 1000 \\
Coefficient (a) & 0.0241 & 0.0257 & 0.0241 & 0.0240 & 0.0261 & 0.0226 \\
Std. Error & 0.0004 & 0.0002 & 0.0010 & 0.0003 & 0.0002 & 0.0001 \\
\hline
\end{tabular}

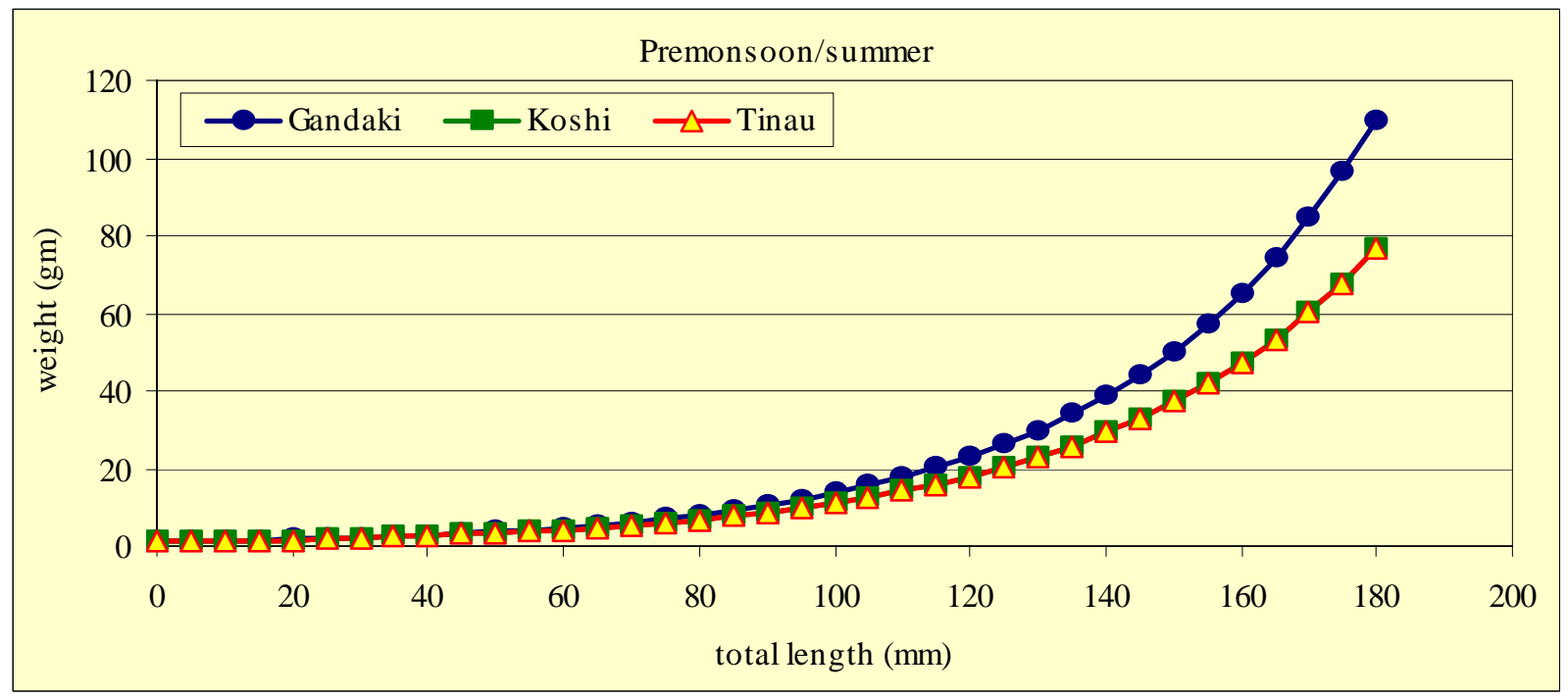

Figure 3: Length-weight relationship of Garra gotyla gotyla in different river systems in pre-monsoon season 


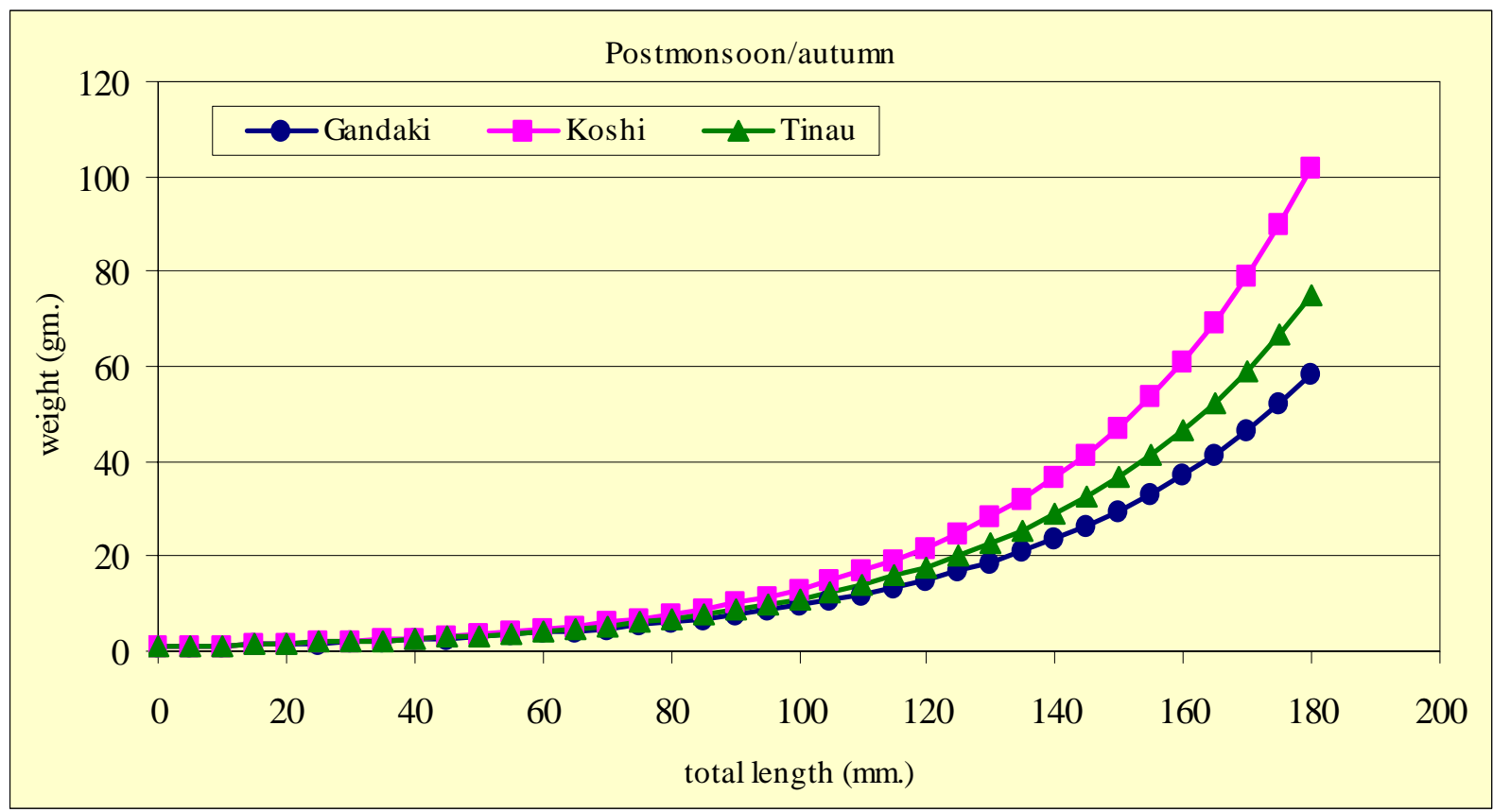

Figure 4 : Length-weight relationship of Garra gotyla gotyla in different river systems in post- monsoon season

On the other hand, the Gandaki System had higher coefficient in pre-monsoon (0.0261) compared to post monsoon (0.0226). The growth in Tinau System was found to be more or less consistence in the two seasons. The regression showed that a sucker head with total length of $180 \mathrm{~mm}$. measured around $76 \mathrm{gm}$ in pre-monsoon in contrast to $102 \mathrm{gm}$. in post monsoon in Koshi System. Similarly the species with the same length measured around 110 $\mathrm{gm}$. in pre-monsoon and around $58 \mathrm{gm}$. in post monsoon in Gandaki system, a remarkable difference. The sucker heads of Tinau System for the same length, however, measured around $75 \mathrm{gm}$. in both the seasons.

\section{Discussion and Conclusion}

The length-weight relationship of most of the fish species found in Nepal has not been worked out and hence there are hardly any literatures to refer and make comparison. The length-weight relationship of the sucker head was found to vary in space and time. Looking at the relationship in different river systems of Nepal for this species, it was found that Koshi System provided the optimum growth, and the stock there were the healthiest. The Gandaki System, from where the largest numbers of sucker head collected were found to be with very fluctuating biomass. Whereas, Tinau had the intermediate but consistent length-weight relationship. The absence of $20 \mathrm{~mm}$ category of sucker heads in Jhikhukhola of the Koshi System indicated that the main channel of this river is not so suitable for the breeding, but presence of higher length groups suggested that the river might be very suitable for the growing fishes. As the river flows through highly agricultural area, there could be very high amount of nutrient in the river due to overflow and hence the optimum growth of the species. However, there was only one river from Koshi system that had been sampled and that too in the highly agricultural area, more rivers and streams of Koshi System has to be sampled to make comparison with Gandaki System, which already has the sample from six different rivers. The length-weight relationship of the species from the Gandaki System should be very near to the normal relationship due to many reasons such as, the high number of sampled rivers, the high number of the species collected, and the presence of all the length groups. Seasonal variations in length-weight relationship of the sucker heads here showed interesting regressions and revealed the aspects of life history as well as the period of stress. Tinau river, with the largest number of sucker heads recorded during this work and with intermediate but good length-weight relationship was found to hold good stock and biomass. The unusually low number of the fish species recorded in premonsoon season due to massive poisoning, however has decreased the correlation and increased the standard error $\left(\mathrm{R}^{2}=0.67420788\right.$ and Std. Error $=$ 0.0010), suggesting that more sampling has to be done in the river in this season. The highest biomass 
was found to be in pre-monsoon. The first reason for that is the optimum growth of gonads as it is the beginning of the breeding season. The other reasons could be the warm temperature and the high availability of foods and organic matter. The autumn had the weakest relationship and hence the least biomass except in the Jhikhukhola of Koshi System. It is simply because it marks the end of breeding season and hence the gonads are emptied. In addition, the stocks have to face massive floods due to monsoon and are in great physiological stress. Winter and spring had an intermediate length-weight relationship. Between autumn to winter, the sucker heads were found to gain weight rapidly, but between winter to spring they marginally lose the weight. It may be due to the plunge in temperature and subsequent coldness that puts them in some kind of physiological stress. However, after spring another phase of gaining weight was noticed which peaked in pre-monsoon season. After spring, temperature gradually increases and so are the foods and nutrients in water. Garra gotyla gotyla has a potential to become more than minor fisheries in Nepal as could be evident from its distribution and abundance. The information regarding its habitat condition, life history, abundance, health, biomass and other population characteristics are important to raise it into a major fishery program. The most important parameters to gather those information are the length and weight and their relationship. This study has tried to give some baseline information on the sucker heads regarding these parameters. Like in any natural fish population, this relationship was found to vary in space and time for this species as well. The relationship also highlights the havoc created by monsoon in their life history and habitat. A careful study of this information should help to estimate its growth, health and stock size, which are so important in fisheries management.

\section{Acknowledgements}

The authors acknowledge the support of Kathmandu University, Universität für Bodenkultur, Austrian Exchange Service (ÖAD) and IUCN, Nepal for this work. Authors also acknowledge the effort of the entire team during fieldwork of this study.

\section{References}

Ataur Rahman, A. K., Freshwater fishes of Bangladesh. The Zoological Society of Bangladesh, Department of Zoology, University of Dhaka, 1989
Bagenal, T. B. and F. W. Tesch, Age and growth. In T. B. Bagenal, (eds), Methods for assessment of fish production in freshwaters. Blackwell Scientific Publications, Oxford, London, 101-136, 1978

Morato, T., P. Afonso and P. Lourhino, Length-weight relationships for 21 coastal fish species of the Azores, north-eastern Atlantic. Fish. Res., 50 (3): 297-302, 2001

Neumann, R. M. and M. S. Allen, Analysis and interpretation of freshwater fisheries data. Department of Natural Resources Management and Engineering, University of Connecticut, 2001

Rajbanshi, K. G., A general bibliography on fish and fisheries of Nepal. Royal Nepal Academy, Kathmandu, Nepal, 1982

Sharma, C. K., River Systems of Nepal. Mrs. Sangeeta Sharma, Bishalnagar, Kathmandu, Nepal, 1977

Shrestha, J., Fish, fishing implements and methods of Nepal. Smt. M.D. Gupta, Lalitpur colony, Lashkar (Gwalior), India, 1994

Shrestha, J., Coldwater fish and fisheries in Nepal. In Petr, T. (Eds), Fish and fisheries at higher altitudes. Asia. FAO Fish. Tech. Pap. . FAO, Rome, (385): 13-40, 1999

Shrestha, J., Taxonomic revision of fishes of Nepal. In P. K. Jha, S. R. Baral, S. B. Karmacharya, (Eds), Environment and Agriculture: Biodiversity, Agriculture and Pollution in South Asia. Ecological Society (ECOS), Kathmandu, Nepal, 171-180, 2001

Shrestha, T. K., Resource ecology of the Himalayan waters. Curriculum Development Center, Tribhuvan University, Kathmandu, Nepal, 1990

Swar, D. B., The status of cold water fish and fisheries in Nepal and prospects of their utilization for poverty reduction. Directorate of fisheries development, Central fisheries building, Balaju, Kathmandu, Nepal, 2001

Talwar, P. K. and A. G. Jhingran, Inland fishes of India and adjacent countries, Oxford and IBH Publishing Company Pvt. Ltd., New Delhi, 1 and 2, 1991

World wide web electronic publication: Fish Base. Available at: http://www.fishbase.org Accessed 5 June 2004 